\title{
Pot k samostojnosti učencev z motnjo v duševnem razvoju: učenje umivanja rok s pomočjo vidnih podpor
}

\author{
Eva Rustja \\ Osnovna šola Franceta Bevka Tolmin \\ eva.rustja@gmail.com \\ Karmen Drljić \\ Univerza na Primorskem \\ karmen.drljic@pef.upr.si
}

\begin{abstract}
Vidne podpore kot znanstveno podprt pristop lahko prispevajo k povečanju samostojnosti in neodvisnosti učencev z motnjami v duševnem razvoju, saj so jim v pomoč pri učenju, razvijanju vseživljenjskih spretnosti ter s tem pri vključevanju v socialno okolje. Ugotavljali smo ustreznost pristopa vidnih podpor za razvoj samostojnosti pri umivanju rok pri učencih z zmernimi motnjami v duševnem razvoju. V raziskavo je bilo vključenih šest učencev. Učence smo najprej spremljali tri dni pred uvedbo vidnih podpor, sledili so petdnevno uvajanje vidnih podpor s pomočjo zgleda in vodene uporabe ter nato še petdnevno obdobje spremljanja samostojne uporabe vidnih podpor. Izboljšanje samostojnosti smo potrdili na ravni celotnega vzorca ter pri dveh učencih. Pri treh učencih je bil zaznan napredek, ki ni bil statistično značilen. Pri enem učencu napredka nismo zaznali. Pristop vidnih podpor je koristen pri razvijanju samostojnosti učencev z motnjami v duševnem razvoju in s tem pri doseganju njihove večje neodvisnosti.
\end{abstract}

Ključne besede: vidne podpore, prehod v samostojnost, umivanje rok, motnja $v$ duševnem razvoju, posebni program vzgoje in izobraževanja

\section{Uvod}

Z uveljavljanjem inkluzivne paradigme je bilo prepoznano, da so vsi učenci učljivi ne glede na njihove morebitne posebne potrebe (Hart in Drummond 2014). Posledično se je uveljavilo stališče, da morata biti tudi vzgoja in izobraževanje učencev z motnjo v duševnem razvoju (v nadaljevanju MDR) usmerjena $v$ razvijanje vseživljenjskih in akademskih spretnosti za njihovo uspešno vključevanje v družbo. MDR lahko namreč pomembno ovirajo učenčev razvoj in funkcioniranje na različnih področjih. Prav zato je učencem z MDR treba zagotoviti čim več priložnosti za prilagojeno doseganje ciljev, ki so v skladu z njihovimi zmožnostmi (Thompson, Shogren in Wehmeyer 2016), ter za uče- 
nje samostojnosti (Quinn 2016) in s tem prehod v neodvisno življenje. MDR zajema skupino etiološko različnih razvojnih stanj, za katere je značilna oviranost kognitivnega funkcioniranja ter prilagoditvenih funkcij in spretnosti, ki se pojavijo že v otroštvu (Salvador-Carulla idr. 2011 v Mahour in Panday 2015; ICD-11 b. I.). Ločimo tri ravni prilagoditvenega funkcioniranja (oz. vedenja): konceptualno, socialno in praktično (American Psychiatric Association 2013). V pričujočem prispevku izpostavljamo predvsem slednje, saj jih osebe z MDR potrebujejo v vsakodnevnih življenjskih okoliščinah za doseganje čim večje samostojnosti. Praktično prilagoditveno funkcioniranje zajema posameznikovo zmožnost skrbeti zase, za svoje zdravje, dobro počutje, splošno higieno, usmerjanje lastnega vedenja ipd. (American Psychiatric Association 2013). Težja kot je oblika MDR, več težav lahko pričakujemo pri posameznikovem usvajanju spretnosti z omenjenega področja. Osebe z zmernimi MDR, ki so predmet naše raziskave, predvidoma lahko usvojijo temeljne spretnosti prilagoditvenega funkcioniranja, a obenem potrebujejo stalno podporo drugih oseb, da lahko ohranjajo dokaj samostojno življenje (ICD-11 b. I.). V tem prispevku se tako osredotočamo na razvijanje samostojnosti učencev z MDR, natančneje na njihove zmožnosti skrbeti za lastno higieno oz. skrbno umivanje rok s pomočjo vidnih podpor ( $v$ nadaljevanju VP).

\section{Razvijanje samostojnosti pri učencih z motnjami v duševnem razvoju}

Prehajanje $v$ samostojno življenje predstavlja ključni vidik razvoja oseb $z$ MDR in je obenem kritično obdobje $v$ njihovem življenju. Prehod lahko razumemo kot statično dejanje - prehod iz enega stanja v drugo - oz. kot dinamično dejanje, torej prehajanje iz enega stanja $v$ drugo $v$ smislu posameznikovega učenja in razvoja (Bouck in Park 2019). Pri osebah z MDR je ta prehod oz. prehajanje usmerjeno predvsem $v$ vzpostavljanje in ohranjanje samostojnega življenja, predvsem za pridobitev zaposlitve ter s tem doseganje kakovosti življenja. Samostojno življenje dosegajo tudi tako, da razvijajo vseživljenjske spretnosti, med katere sodi tudi skrb zase. Na ta način zmanjšujejo odvisnost od drugih in povečujejo nadaljnje vključevanje $v$ družbo (Servatius, Fellows in Kelly 1992 v Koyama in Wang 2011).

Učenci z zmernimi do težjimi MDR so med šolanjem praviloma vključeni v posebni progam vzgoje in izobraževanja, $v$ okviru katerega imajo predmet, namenjen razvijanju samostojnosti. Ta se izvaja tedensko $v$ obsegu od štiri do osem ur $^{1}$ (Grubešič 2014). Usmerjeno in neposredno učenje vseživljenjskih

\footnotetext{
${ }^{1}$ Učenci prve stopnje imajo vsa tri leta na urniku osem ur tedensko predmet s področja razvijanja
} samostojnosti, na drugi stopnji vsa tri leta sedem in na tretji vsa tri leta pet ur na teden. Na četrti 
spretnosti je torej eden izmed pomembnejših ciljev vzgoje in izobraževanja učencev z MDR (Ministrstvo za šolstvo in šport 2004). Pri tem jim je treba zagotoviti ustrezno podporo (Stokes, Turnbull in Wyn 2013) ter raznolike, naravne socialne situacije za učinkovitejši transfer znanja v novo okolje (Ministrstvo za šolstvo in šport 2004; Buckley idr. 2006). Ključnega pomena pri učenju samostojnosti pa je tudi, da učenci ne razvijejo odklonilnega odnosa do izgrajevanja določene spretnosti (Dyrbjerg in Vedel 2007).

Različni pristopi učenja samostojnosti učencev z MDR poudarjajo pomen neposrednega in strukturiranega učenja in poučevanja, pri čemer se zmanjša uporaba učenčeve odvisnosti od odraslega (Hannah 2009). V splošnem lahko pristope razvijanja samostojnosti razdelimo na (1) vedenjske, katerih namen je spodbuditi želeno vedenje pri učencu, in (2) pristope s pomočjo spodbujanja in učenja komunikacije. V prvem primeru določeno vedenje razdelimo na manjše korake, tako postanejo za učenca obvladljivejši; doseženo želeno vedenje nagradimo, neželeno vedenje pa popravimo. Vedenjski pristopi imajo pomembne trajne učinke, ki so znanstveno podprti (DeBoer 2007 v Jurišić 2011). V drugem primeru se osredotočamo na učenje komunikacije učencev z izrazitimi govornimi primanjkljaji (Mitchell 2014; Charlop-Christy idr. 2002). Med slednje uvrščamo tudi pristop vidne podpore ( $v$ nadaljevanju VP), na katerega se podrobneje osredotočamo v nadaljevanju.

\section{Vidne podpore pri razvijanju samostojnosti učencev $z$ motnjami v duševnem razvoju}

VP so znanstveno potrjen pristop (Rao in Gagie 2006). Različne študije navajajo, da so pomembne pri uravnavanju vedenja učencev; ustrezno uvedene povečujejo samostojnost tako učencev s posebnimi potrebami kot tudi učencev z MDR (Duttlinger idr. 2013; Spriggs, van Dijk in Mims 2015; Van Laarhoven idr. 2009; Hall idr. 1995 v Mitchell 2014). Ena izmed njihovih pomembnejših funkcij je torej preko vidnih namigov učencem s posebnimi potrebami pomagati k večji samostojnosti (Cohen in Gerhardt 2016). Uporabljamo jih pri učenju vzpostavljanja socialne interakcije in komunikacije, pri prehodih med dejavnostmi, organizaciji učnega okolja, za prikaz navodil (npr. za pozdravljanje, umivanje zob) ter pri izražanju pričakovanega vedenja v socialnih okoliščinah in s tem zmanjševanju vedenjskih težav (Meadan idr. 2011; Jurišić 2016). Z njihovo pomočjo lahko učenci z MDR izražajo tudi svoje misli, občutja in potrebe (Rao in Gagie 2006). VP omogočajo večjo samostojnost učen-

in peti stopnji so predvidene štiri ure s tega področja na teden. Šesta stopnja ima prvi dve leti pet ur, drugi dve leti štiri in v zadnjem letu tri ure na teden (Grubešič 2014). 
cem z MDR tudi zato, ker jim zagotavljajo jasno strukturo in predvidljivost ter ustvarjajo občutek varnosti (Hodgdon 1995 v Meadan idr. 2011). Učinkovite so tudi pri ohranjanju pozornosti (Rao in Gagie 2006; Dyrbjerg in Vedel 2007). Poglavitna vloga VP je usmerjanje lastnega vedenje $v$ odsotnosti odraslega (Koyama in Wang 2011), s čimer zmanjšujejo odvisnost učenca od drugega.

Poznamo različne oblike VP: kretnje/znakovni jezik (Demšar 2017; Cohen in Gerhardt 2016; Wilken 2012), slike in fotografije (Demšar 2017; Cohen in Gerhardt 2016; Meadan idr. 2011), grafične predstavitve (Cohen in Gerhardt 2016), vizualni urniki (Dyrbjerg in Vedel 2007; Hannah 2009; Meadan idr. 2011), VP, ki organizirajo okolje (Cohen in Gerhardt 2016; Meadan idr. 2011), socialne zgodbe (Hannah 2009; Meadan idr. 2011; Rao in Gagie 2006; Gray 2010), navodila za opravljanje zaporedja korakov določene rutine (Hannah 2009; Cohen in Gerhardt 2016). Za učinkovite so se izkazale predvsem slednje, in sicer tako pri enostavnih rutinah kot pri kompleksnih (Koyama in Wang 2011). Učenje rutine s pomočjo VP je uspešno predvsem pri učencih, ki pozabljajo zaporedne korake, zamenjujejo njihov vrstni red, hitro izgubijo pozornost ali so pretirano odvisni od spodbude učitelja (Hannah 2009; Meadan idr. 2011). Izbira oblike VP mora biti individualizirana glede na specifične potrebe učenca z MDR in njegove zmožnosti. Če želimo doseči večjo učinkovitost VP, je za uspešno izvedeno rutino s pomočjo VP pomembno tudi nagrajevanje učenca (Rao in Gagie 2006).

Pri uvajanju VP je najpomembnejše, da jih učenec večkrat preskusi v spremstvu odraslega, ki mu nudi podporo ter preverja njegovo razumevanje. Učenje mora biti sistematično. Različni raziskovalci predlagajo različne načine uvajanja VP (Rao in Gagie 2006; Meadan idr. 2011; Cohen in Demchak 2018). Raova in Gagiejeva (2006) tako npr. naštevata naslednje korake: (1) učenje s preizkušanjem, kjer spretnosti, ki jih želimo naučiti, razstavimo na manjše korake; (2) odločitev o primerni VP za vsak posamezen korak; (3) individualno učenje uporabe VP; (4) spodbujanje in izbira ustreznega sistema nagrajevanja za spodbujanje pravilne uporabe VP ter (5) opuščanje uporabe VP. Sistematično učenje uporabe VP je torej nujno, saj se zgolj demonstracija njihove uporabe ne izkaže za učinkovito (Meadan idr. 2011) in tako ne prispeva k povečanju samostojnosti učenca (Cohen in Demchak 2018). S povečevanjem samostojnosti učencev $z$ MDR pa je lahko uspešnejši tudi njihov prehod v neodvisno življenje.

\section{Raziskovalni problem}

Učence z MDR je treba opremiti z uporabnimi znanji in jim tako omogočiti čim večjo samostojnost, da bodo lahko dosegali karseda neodvisno življe- 
nje. Zato je učenje skrbi zase $v$ okviru področja razvijanja samostojnosti le ena izmed veščin, ki jih razvijamo. Učenci z MDR potrebujejo pri učenju skrbi zase različne spodbude, med katere uvrščamo tudi VP. Nekateri strokovnjaki pripisujejo pristopu VP velik pomen (npr. Rao in Gagie 2006, Spriggs, van Dijk in Mims 2015; Van Laarhoven idr. 2009). VP pritegne posameznikovo pozornost in jo tudi nekaj časa zadrži ter mu tako omogoča, da se osredotoči na sporočilo, in zmanjša njegovo anksioznost. Uvedba VP v kombinaciji s sistematičnim učenjem njihove uporabe prispeva $k$ učenju samostojnosti učencev z MDR. Raziskave (npr. Jurišić 2016; Pierce in Schreibman 1994; Rao in Gagie 2006) potrjujejo, da VP pomembno prispevajo k razvoju samostojnosti pri izvajanju dejavnosti in nalog. Za učinkovite so se izkazale tudi pri učenju samostojnega umivanja rok (Cohen in Demchak 2018). Posledično lahko VP prispevajo $k$ doseganju samostojnega življenja učencev $z$ MDR pri prehajanju ali na prehodu v odraslost. Zato smo v okviru študije primera želeli raziskati, kako ustrezen je pristop uporabe VP pri učenju samostojnega umivanja rok učencev z zmernimi MDR.

\section{Metodologija}

\section{Vključeni v raziskavo}

$V$ raziskavi je sodelovalo šest učencev, starih med 8 in 18 let, ${ }^{2}$ z zmerno motnjo $v$ duševnem razvoju, ki obiskujejo posebni program vzgoje in izobraževanja na eni izmed slovenskih šol in so se v času raziskave usposabljali na I., III., IV. ter V. stopnji posebnega programa vzgoje in izobraževanja. Pri štirih od šestih učencev se motnja $v$ duševnem razvoju sopojavlja z drugimi motnjami (avtizem in Downov sindrom). Med vključenimi učenci je bila ena učenka in pet učencev. Pri razlagi rezultatov bomo vse udeležence nazivali v moški obliki, da bi se izognili razkritju identitete udeleženke.

Udeležence raziskave smo izbrali glede na to, ali so si bili v fazi opazovanja samostojnosti pri umivanju rok s pomočjo VP sposobni roke umiti sami ali ne. Učencev, ki so si v času opazovanja roke umivali povsem samostojno in v pravilnem vrstnem redu ali so izražali kljubovalno vedenje, nismo vključili v raziskavo.

\section{Proces zbiranja podatkov}

Podatke smo zbirali tako, da smo pri vključenih $v$ raziskavo uvajali VP, katerih namen je bil doseči samostojnost pri umivanju rok. Zbiranje podatkov je potekalo $v$ treh fazah, in sicer: (I) prva je faza opazovanja, kjer smo opazovali,

\footnotetext{
${ }^{2}$ Dva učenca sta bila stara med 8 in 12 let, štirje učenci med 12 in 18 let.
} 
koga bomo vključili v raziskavo; (II) druga je faza uvajanja VP, kjer smo uvedli VP za umivanje rok po petih korakih: (1) zmočim roke $z$ vodo, (2) nanesem milo, (3) drgnem roke, (4) roke sperem z vodo in (5) obrišem roke; (III) tretja je faza spremljanja, kjer smo pri umivanju rok spremljali učence pri samostojni uporabi VP. Učenci so si roke umivali pri istem lijaku, kot to počnejo običajno v šoli, tako da jim okolje ni bilo novo in nismo posegali v njihovo običajno rutino umivanja. $V$ nadaljevanju podrobneje opisujemo posamezno fazo.

$\checkmark$ prvi fazi, to je $v$ fazi opazovanja, smo tri dni pred začetkom uvajanja vidnih podpor učence, vključene $v$ raziskavo, $z$ namensko oblikovano opazovalno listo opazovali, kako samostojno izvedejo postopek umivanja rok. Opazovalno listo smo oblikovali tako, da smo $v$ njej zajeli pet stopenj pomoči; najnižja stopnja samostojnosti je pomenila, da učenec potrebuje popolni telesni namig, sledil je delni telesni namig, nato verbalni namig, namig s kretnjo, najvišja stopnja pa je pomenila, da učenec korak opravi samostojno in ne potrebuje pomoči. $V$ tej fazi je devet učencev dobilo navodilo: „Umij si roke.« Izločili smo tri učence: dva učenca, ki sta si samostojno umivala roke, ter enega učenca, ki je pokazal kljubovalen odnos. Fazi opazovanja je sledilo uvajanje VP, ki je trajalo pet dni. Učencem smo predstavili VP, se z njimi pogovorili o posameznih slikah in jih skupaj z njimi nalepili nad lijak, kjer si pred šolsko malico ali kosilom običajno umivajo roke. Umivanje rok s pomočjo VP smo učencem tudi demonstrirali in ob tem verbalno opisali postopek. Dodatno smo jih spodbujali, napake popravljali in jih ob dobro opravljeni nalogi pohvalili. $V$ tej fazi podatkov o potrebni pomoči nismo zapisovali, ker je bil namen uvajanja učenje samostojne uporabe VP. V fazi spremljanja smo z že zgoraj omenjeno opazovalno listo beležili podatke o tem, kako samostojen je bil posamezen učenec pri umivanju rok z uporabo VP. Navodilo, ki so ga učenci prejeli, se je glasilo: „Učenec $X$, umij roke, ker sledi malica/kosilo." $\checkmark$ tem delu smo želeli biti čim neopaznejši, po potrebi smo učencu pomagali na čim manj opazen način, da je korak izpeljal pravilno. Ob dokončanju naloge smo učence pohvalili ali jih nagradili s petko, prav tako so bili seznanjeni s tem, da jih po opravljeni nalogi čaka malica ali kosilo, kar je za tovrstne učence eden izmed večjih motivatorjev. Roke so si umivali pred malico ali kosilom, ker je to praviloma rutina, ki jo je pred jedjo vedno potrebno opraviti in so takega načina tudi navajeni.

\section{Proces obdelave podatkov}

Pridobljene rezultate smo prikazali s pomočjo diagramov potrebne pomoči po korakih za obdobji opazovanja pred uvajanjem in spremljanja po uvajanju VP. Diagrami aritmetične sredine in regresijske premice potrebne pomoči so 
prikazani po dnevih za obdobje opazovanja pred uvajanjem in za obdobje spremljanja po uvajanju VP; oblikovani so za posameznega učenca. Stopnjo pomoči smo prevedli iz nominalne $v$ ordinalno spremenljivko po naslednjem ključu: 1 - popolni telesni namig, 2 - delni telesni namig, 3 - verbalni namig, 4 - namig s kretnjo in 5 - samostojna izvedba.

$V$ diagramu aritmetične sredine in regresijske premice potrebne pomoči po dnevih za obdobji opazovanja pred uvajanjem in spremljanja po uvajanju VP smo predstavili srednje vrednosti potrebne pomoči za vseh pet korakov skupaj za vsak dan. ${ }^{3} \mathrm{Na}$ diagramih smo poleg krivulje, ki je povezovala aritmetične sredine za posamezen dan, s pomočjo funkcije programa Microsoft Excel izvedli linearno regresijo ter graf opremili z regresijsko premico. Regresijski koeficient enačbe nam je podajal smer trenda, ki ga nakazuje regresijska premica, koeficient determinacije pa je služil kot informacija o količini variance spremenljivke, ki smo jo pojasnili s pomočjo linearne regresije.

Izvedli smo tudi primerjavo srednjih vrednosti potrebne pomoči pred uvajanjem VP in po njem s pomočjo statističnega programa JASP (https://jaspstats.org). Za učence 1, 3, 4 in 5 smo uporabili neparametrični Wilcoxonov preizkus, saj nismo mogli zadostiti predpostavki o normalnosti porazdelitve spremenljivk. Pri učencih 2 in 6 so imele vse vrednosti v vzorcu potrebne pomoči enako vrednost, zato spremenljivka ni imela variance, posledično smo uporabili Wilcoxonov preizkus $v$ sklopu primerjave srednje vrednosti s teoretično vrednostjo. Dodatno smo izvedli še $t$-preizkus povezanih vzorcev, $\mathrm{s}$ katerim smo primerjali srednje vrednosti potrebne pomoči celotnega vzorca za obdobji pred in po uvajanju VP.

\section{Rezultati in razprava}

$V$ nadaljevanju predstavljamo rezultate za posameznega učenca, in sicer najprej diagram potrebne pomoči, ki prikazuje rezultate, pridobljene $v$ fazi opazovanja in fazi spremljanja za posameznega učenca pri umivanju rok. Diagram aritmetične sredine potrebne pomoči pri umivanju rok prikazuje vrednost potrebne pomoči med opazovanjem in spremljanjem za posameznega učenca. Za vsakega izmed njih so prikazani rezultati korelacijskega koeficienta regresijske premice, iz katere so razvidni količina pomoči na dnevni ravni ter rezultati Wilcoxonovega preizkusa.

Iz preglednice potrebne pomoči po dnevih za učenca 1 (preglednica 1) je razvidno, da mu največ težav povzročata koraka (3) in (4). Vse tri dni opazovanja je pri koraku (3) potreboval verbalne namige, medtem ko je pri koraku

\footnotetext{
${ }^{3}$ Tri dni opazovanja pred uvajanjem in pet dni spremljanja po uvedbi vidnih podpor.
} 
Preglednica 1 Potrebna pomoč po korakih za obdobji opazovanja pred uvajanjem in spremljanja po uvajanju vidnih podpor pri učencu 1

\begin{tabular}{lrrrrrrrr}
\hline Koraki & \multicolumn{1}{c}{ Dnevi } \\
\cline { 2 - 10 } & 1 & 2 & 3 & 4 & 5 & 6 & 7 & 8 \\
\hline (1) Zmočim roke z vodo & 5 & 4 & 5 & 4 & 4 & 5 & 5 & 5 \\
(2) Nanesem milo & 5 & 4 & 3 & 5 & 5 & 5 & 5 & 5 \\
(3) Drgnem roke & 3 & 3 & 3 & 5 & 5 & 5 & 5 & 5 \\
(4) Roke dobro sperem z vodo & 3 & 4 & 3 & 4 & 4 & 5 & 5 & 5 \\
(5) Obrišem roke & 5 & 5 & 5 & 5 & 5 & 5 & 3 & 5 \\
\hline Aritmetična sredina & 4.2 & 4.0 & 3.8 & 4.6 & 4.6 & 5.0 & 4.6 & 5.0 \\
\hline
\end{tabular}

Opombe $R^{2}=0.6538$.

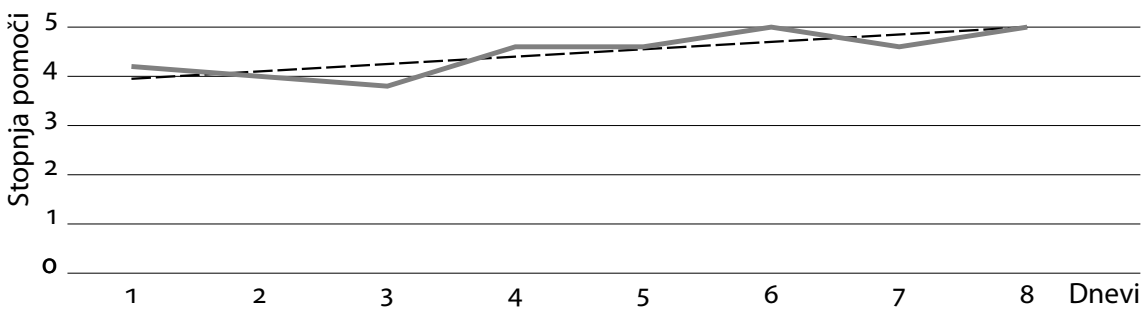

Slika 1 Aritmetična sredina in regresijska premica potrebne pomoči po dnevih za obdobji opazovanja pred uvajanjem in spremljanja po uvajanju vidnih podpor pri učencu 1

(4) prvi in tretji dan potreboval verbalni namig, drugi dan pa namig s kretnjo. $\checkmark$ fazi spremljanja je učenec koraka (2) in (3) izvedel povsem samostojno, le s pomočjo VP. Zadnji korak (5) je vse dni, razen predzadnjega, izvedel samostojno. Ugotovimo, da je bil učenec 1 tretji in peti dan spremljanja pri umivanju rok ob pomoči VP povsem samostojen, pri samostojni izvedbi nekaterih korakov je napredoval, pri drugih pa nazadoval.

Srednja vrednost potrebne pomoči je med opazovanjem učenca 1 (slika 1) pred uvajanjem VP tri dni rahlo upadala ( $z \bar{X}=4,2$ na $\bar{X}=3,8)$, potem pa se je že s prvim dnem spremljanja po uvajanju očitno dvignila $(\bar{X}=4,6)$ in dosegla višek tretji dan. Sledila sta rahel upad in ponoven dvig na maksimalno vrednost. Iz korelacijskega koeficienta regresijske premice je razvidno, da se je potrebna količina pomoči na dnevni ravni v povprečju znižala za 2,04\%. $Z$ linearno regresijo smo uspeli pojasniti $65,38 \%$ celotne variance potrebne pomoči. Wilcoxonov preizkus je pokazal, da kljub opaženim zmanjšanim potrebam po pomoči ne moremo s statistično gotovostjo potrditi, da je učenec 1 pri umivanju rok pridobil na samostojnosti $(P=0,16)$.

Iz preglednice 2 je razvidno, da je učenec $2 v$ fazi opazovanja vse tri dni samostojno opravil koraka (1) in (5). Pri korakih (3) in (4) je vse tri dni poka- 
Preglednica 2 Potrebna pomoč po korakih za obdobji opazovanja pred uvajanjem in spremljanja po uvajanju vidnih podpor pri učencu 2

\begin{tabular}{lrrrrrrrr}
\hline Koraki & \multicolumn{10}{c}{ Dnevi } \\
\cline { 2 - 9 } & 1 & 2 & 3 & 4 & 5 & 6 & 7 & 8 \\
\hline (1) Zmočim roke z vodo & 5 & 5 & 5 & 5 & 5 & 5 & 5 & 5 \\
(2) Nanesem milo & 3 & 3 & 3 & 5 & 5 & 5 & 5 & 5 \\
(3) Drgnem roke & 5 & 3 & 5 & 5 & 5 & 5 & 5 & 5 \\
(4) Roke dobro sperem z vodo & 5 & 3 & 5 & 5 & 5 & 5 & 5 & 5 \\
(5) Obrišem roke & 5 & 5 & 5 & 5 & 5 & 5 & 5 & 5 \\
\hline Aritmetična sredina & 4.6 & 3.8 & 4.6 & 5.0 & 5.0 & 5.0 & 5.0 & 5.0 \\
\hline
\end{tabular}

Opombe $R^{2}=0.4724$.

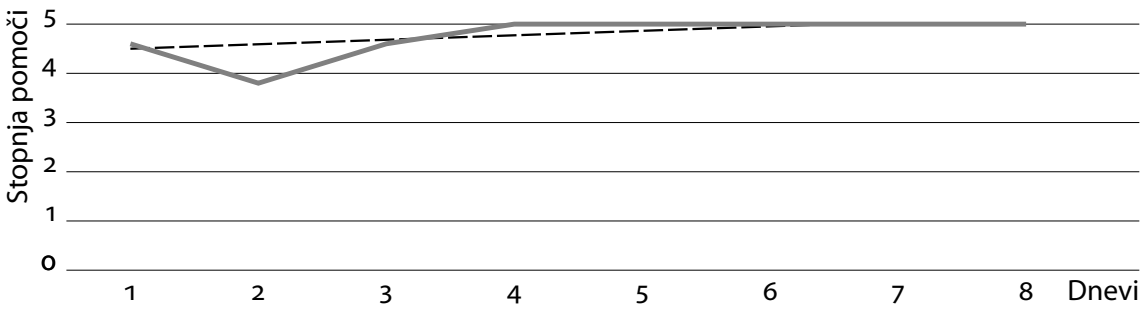

Slika 2 Aritmetična sredina in regresijska premica potrebne pomoči po dnevih za obdobji opazovanja pred uvajanjem in spremljanja po uvajanju vidnih podpor pri učencu 2

zal enake rezultate; prvi in zadnji dan opazovanja ju je izvedel samostojno, medtem ko je drugi dan opazovanja potreboval verbalni namig. $V$ fazi opazovanja je učenec 2 najnižjo stopnjo samostojnosti izkazal pri izvedbi koraka (2). Prikazani rezultati kažejo, da je učenec $2 \mathrm{v}$ fazi spremljanja vseh pet korakov za umivanje rok vseh pet dni opazovanja ob uporabi VP izvajal povsem samostojno.

Srednja vrednost potrebne pomoči v primeru učenca 2 (slika 2) pred uvajanjem VP je tri dni nihala $(\bar{X}=4,6 ; 3,8 ; 4,6)$, potem pa se je že s prvim dnem spremljanja po uvajanju dvignila na maksimalno vrednost $(\bar{X}=5)$ in tam ostala vseh pet dni spremljanja. Iz korelacijskega koeficienta regresijske premice je razvidno, da se je potrebna količina pomoči na dnevni ravni v povprečju znižala za 2,38\%. Z linearno regresijo smo uspeli pojasniti $47,24 \%$ celotne variance potrebne pomoči. Wilcoxonov preizkus je pokazal, da lahko s statistično gotovostjo $(P=0,01)$ trdimo, da je učenec 2 po uvedbi VP za umivanje rok izkazal večjo samostojnost kot $v$ fazi opazovanja.

Iz preglednice 3 je razvidno, da je učenec 3 v fazi opazovanja korak (1) kar dvakrat izvedel samostojno, $v$ fazi spremljanja pa je imel ravno pri tem koraku zabeležene najvišje stopnje pomoči. Pri učencu 3 opazimo, da se je $v$ 
Preglednica 3 Potrebna pomoč po korakih za obdobji opazovanja pred uvajanjem in spremljanja po uvajanju vidnih podpor pri učencu 3

\begin{tabular}{lrrrrrrrr}
\hline Koraki & \multicolumn{1}{c}{ Dnevi } \\
\cline { 2 - 10 } & 1 & 2 & 3 & 4 & 5 & 6 & 7 & 8 \\
\hline (1) Zmočim roke z vodo & 5 & 5 & 3 & 2 & 3 & 3 & 3 & 3 \\
(2) Nanesem milo & 3 & 3 & 3 & 5 & 5 & 5 & 5 & 4 \\
(3) Drgnem roke & 3 & 3 & 3 & 3 & 5 & 5 & 3 & 5 \\
(4) Roke dobro sperem z vodo & 3 & 3 & 3 & 5 & 5 & 5 & 5 & 5 \\
(4) Obrišem roke & 3 & 3 & 3 & 3 & 5 & 5 & 5 & 5 \\
\hline Aritmetična sredina & 3.4 & 3.4 & 3.0 & 3.6 & 4.6 & 4.6 & 4.2 & 4.4 \\
\hline
\end{tabular}

Opombe $R^{2}=0.6176$.

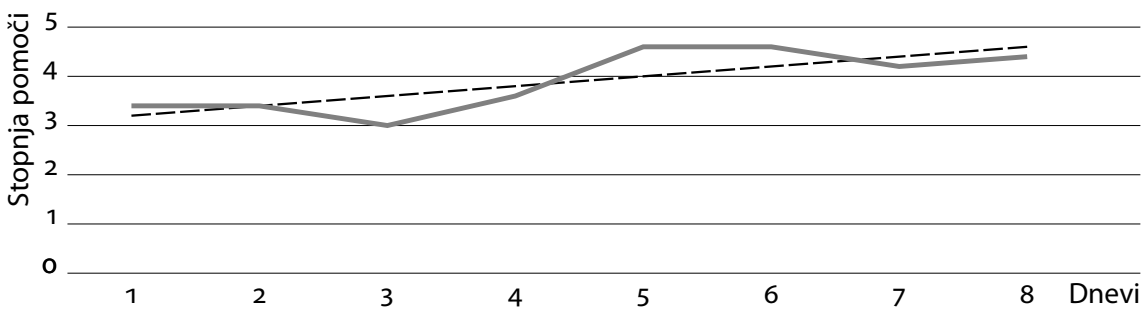

Slika 3 Aritmetična sredina in regresijska premica potrebne pomoči po dnevih za obdobji opazovanja pred uvajanjem in spremljanja po uvajanju vidnih podpor pri učencu 3

fazi spremljanja zmanjšalo število verbalnih namigov. Noben dan si ni uspel samostojno umiti rok po korakih kljub pomoči VP, je pa drugi in tretji dan korake (2) do (5) uspel izvesti povsem samostojno, kar kaže na višjo stopnjo samostojnosti kot pred uporabo VP.

Srednja vrednost potrebne pomoči med opazovanjem učenca 3 (slika 3) pred uvajanjem vidnih podpor zadnji dan upadla ( $z \bar{X}=3,4$ na $\bar{X}=3,0$ ), potem pa prvi dan spremljanja zrasla na $\bar{X}=3,6$, ostala dva dni pa na $\bar{X}=4,6$, potem znova padla na $\bar{X}=4,2$ in se ponovno dvignila na $\bar{X}=4,4$. Iz korelacijskega koeficienta regresijske premice je razvidno, da se je potrebna količina pomoči na dnevni ravni v povprečju znižala za $4 \%$. $Z$ linearno regresijo smo uspeli pojasniti $61,76 \%$ celotne variance potrebne pomoči. Wilcoxonov preizkus je pokazal, da kljub opaznim zmanjšanim potrebam po pomoči ne moremo z gotovostjo potrditi $(P=0,19)$, da je učenec 3 pri umivanju rok pridobil na samostojnosti.

Iz preglednice 4 je razvidno, da je učenec $4 \mathrm{v}$ fazi opazovanja vse tri dni uspel samostojno opraviti korake (2), (4) in (5). Razvidno je, kakšne spremembe so VP prinesle njegovi samostojnosti: vseh pet dni spremljanja je uspel izvesti korake (1), (2), (4) in (5) povsem samostojno ob pomoči VP. 
Preglednica 4 Potrebna pomoč po korakih za obdobji opazovanja pred uvajanjem in spremljanja po uvajanju vidnih podpor pri učencu 4

\begin{tabular}{lrrrrrrrr}
\hline Koraki & \multicolumn{10}{c}{ Dnevi } \\
\cline { 2 - 9 } & 1 & 2 & 3 & 4 & 5 & 6 & 7 & 8 \\
\hline (1) Zmočim roke z vodo & 3 & 3 & 3 & 5 & 5 & 5 & 5 & 5 \\
(2) Nanesem milo & 5 & 5 & 5 & 5 & 5 & 5 & 5 & 5 \\
(3) Drgnem roke & 3 & 3 & 3 & 5 & 5 & 5 & 3 & 5 \\
(4) Roke dobro sperem z vodo & 5 & 5 & 5 & 5 & 5 & 5 & 5 & 5 \\
(5) Obrišem roke & 5 & 5 & 5 & 5 & 5 & 5 & 5 & 5 \\
\hline Aritmetična sredina & 4.2 & 4.2 & 4.2 & 5.0 & 5.0 & 5.0 & 4.6 & 5.0 \\
\hline
\end{tabular}

Opombe $R^{2}=0.5411$.

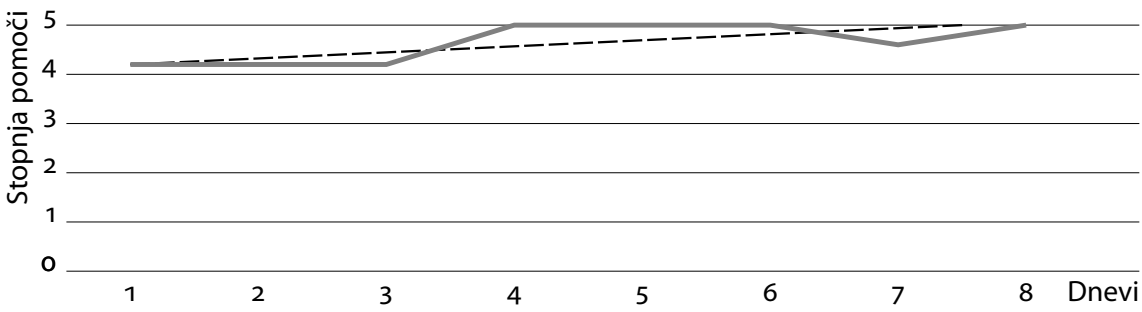

Slika 4 Aritmetična sredina in regresijska premica potrebne pomoči po dnevih za obdobji opazovanja pred uvajanjem in spremljanja po uvajanju vidnih podpor pri učencu 4

Pri učencu 4 (slika 4) je bila potrebna količina pomoči v fazi opazovanja konstantna $(\bar{X}=4,2)$. Po uvajanju vidnih podpor učenec 4 ni več potreboval pomoči, razen četrti dan pri enem koraku. Srednje vrednosti nudene pomoči v fazi spremljanja so torej imele štiri dni vrednost $\bar{X}=5$, en dan pa $\bar{X}=4,6$. Iz korelacijskega koeficienta regresijske premice je razvidno, da se je potrebna količina pomoči na dnevni ravni v povprečju znižala za 2,38 \%. Z linearno regresijo smo uspeli pojasniti 54,11\% celotne variance potrebne pomoči. Wilcoxonov preizkus je pokazal, da kljub opaznim zmanjšanim potrebam po pomoči ne moremo s statistično gotovostjo potrditi, da je učenec 4 pri umivanju rok pridobil na samostojnosti $(P=0,18)$.

Iz preglednice 5 je razvidno, da je bil učenec 5 pri korakih (1) in (3) samostojen vse tri dni opazovanja. Pri koraku (5) je bil samostojen le prva dva dni. Najnižjo stopnjo samostojnosti je učenec 5 izkazal pri izvajanju koraka (4). Učenec 5 je $v$ fazi spremljanja uspel ob pomoči VP vseh pet dni samostojno izvesti zadnji korak. Pri koraku (4), ki mu je v fazi opazovanja povzročal največ težav, je napredoval. Kljub uporabi VP si učenec 5 rok noben dan ni uspel umiti povsem samostojno.

Učenec 5 (slika 5) je najvišjo stopnjo samostojnosti izkazal drugi dan tri- 
Preglednica 5 Potrebna pomoč po korakih za obdobji opazovanja pred uvajanjem in spremljanja po uvajanju vidnih podpor pri učencu 5

\begin{tabular}{lrrrrrrrr}
\hline Koraki & \multicolumn{1}{c}{ Dnevi } \\
\cline { 2 - 9 } & 1 & 2 & 3 & 4 & 5 & 6 & 7 & 8 \\
\hline (1) Zmočim roke z vodo & 5 & 5 & 5 & 4 & 4 & 5 & 3 & 5 \\
(2) Nanesem milo & 4 & 4 & 4 & 5 & 4 & 5 & 3 & 5 \\
(3) Drgnem roke & 5 & 5 & 5 & 3 & 4 & 5 & 5 & 3 \\
(4) Roke dobro sperem z vodo & 2 & 5 & 2 & 5 & 5 & 2 & 2 & 5 \\
(5) Obrišem roke & 5 & 5 & 3 & 5 & 5 & 5 & 5 & 5 \\
\hline Aritmetična sredina & 4.2 & 4.8 & 3.8 & 4.4 & 4.4 & 4.4 & 3.6 & 4.6 \\
\hline
\end{tabular}

Opombe $R^{2}=0.0105$.

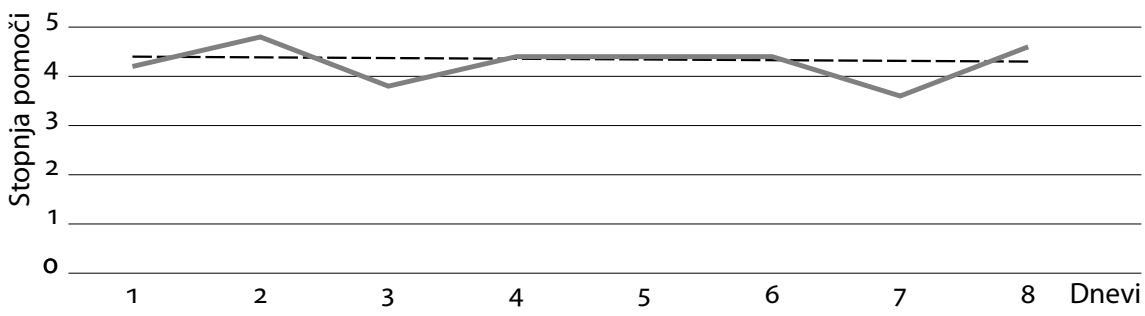

Slika 5 Aritmetična sredina in regresijska premica potrebne pomoči po dnevih za obdobji opazovanja pred uvajanjem in spremljanja po uvajanju vidnih podpor pri učencu 5

dnevnega opazovanja pred uvajanjem vidnih podpor, tretji dan je sledil upad na $\bar{X}=3,8$, temu je po uvajanju sledilo zvišanje samostojnosti $(\bar{X}=4,4)$, najnižjo stopnjo samostojnosti je dosegel četrti dan spremljanja $(\bar{X}=3,6)$, zadnji dan spremljanja pa je sledilo ponovno zvišanje $(\bar{X}=4,6)$. Iz korelacijskega koeficienta regresijske premice je razvidno, da se je potrebna količina pomoči na dnevni ravni v povprečju zvišala za o,33\%. Z linearno regresijo smo uspeli pojasniti zgolj 1,05\% celotne variance potrebne pomoči. Z Wilcoxonovim preizkusom nismo zaznali statistično značilnih sprememb v samostojnosti med obdobjema pred in po uvajanju vidnih podpor za umivanje rok ( $P=$ o,97).

Iz preglednice 6 razberemo, da je učenec 6 pred uvedbo VP uspel samostojno izvesti korake (3), (4) in (5). Najnižjo stopnjo samostojnosti je pokazal pri koraku (1), ki ga noben dan opazovanja ni uspel izvesti samostojno. Učenec 6 je pri samostojnem umivanju korak (1) preskočil in umivanje začel z nanosom mila na suhe roke. Ko smo to zaznali, smo ga zaustavili in mu ponudili pomoč, da je njegov proces umivanja pravilno stekel. S pomočjo VP je učenec 6 postal samostojen pri umivanju rok.

Pri učencu 6 (slika 6) je za obdobje prvih treh dni opazovanja razvidna kon- 
Preglednica 6 Potrebna pomoč po korakih za obdobji opazovanja pred uvajanjem in spremljanja po uvajanju vidnih podpor pri učencu 6

\begin{tabular}{lrrrrrrrr}
\hline Koraki & \multicolumn{10}{c}{ Dnevi } \\
\cline { 2 - 9 } & 1 & 2 & 3 & 4 & 5 & 6 & 7 & 8 \\
\hline (1) Zmočim roke z vodo & 3 & 4 & 3 & 5 & 5 & 5 & 5 & 5 \\
(2) Nanesem milo & 5 & 4 & 5 & 5 & 5 & 5 & 5 & 5 \\
(3) Drgnem roke & 5 & 5 & 5 & 5 & 5 & 5 & 5 & 5 \\
(4) Roke dobro sperem z vodo & 5 & 5 & 5 & 5 & 5 & 5 & 5 & 5 \\
(5) Obrišem roke & 5 & 5 & 5 & 5 & 5 & 5 & 5 & 5 \\
\hline Aritmetična sredina & 4.6 & 4.6 & 4.6 & 5.0 & 5.0 & 5.0 & 5.0 & 5.0 \\
\hline
\end{tabular}

Opombe $R^{2}=0.7143$.

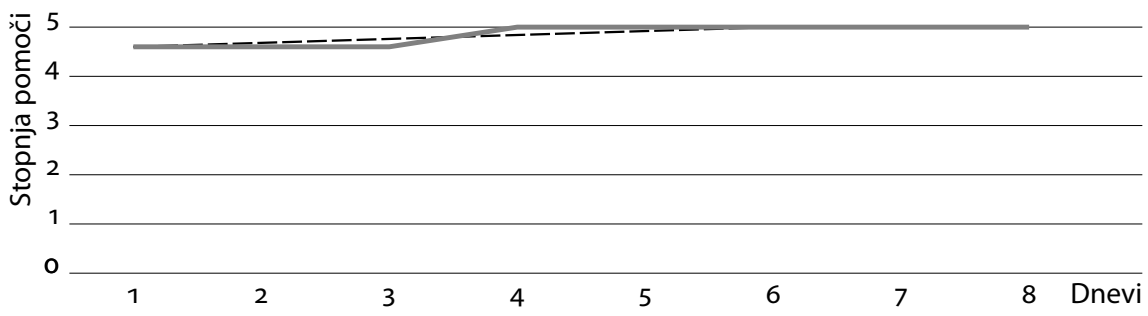

Slika 6 Aritmetična sredina in regresijska premica potrebne pomoči po dnevih za obdobji opazovanja pred uvajanjem in spremljanja po uvajanju vidnih podpor pri učencu 6

stantna vrednost skoraj popolne samostojnosti $(\bar{X}=4,6)$, ki se po uvedbi vidnih podpor zviša na raven popolne samostojnosti $(\bar{X}=5,0)$ in tam ostane vseh pet dni spremljanja. Iz korelacijskega koeficienta regresijske premice je razvidno, da se je potrebna količina pomoči na dnevni ravni v povprečju znižala za 1,43\%. Z linearno regresijo smo uspeli pojasniti $71,43 \%$ celotne variance potrebne pomoči. Wilcoxonov preizkus je pokazal, da lahko s statistično gotovostjo $(P=0,012)$ trdimo, da je učenec 6 po uvedbi VP za umivanje rok izkazal večjo samostojnost kot $v$ fazi opazovanja, kar pomeni, da so mu bile VP v pomoč.

Na podlagi pridobljenih rezultatov lahko učence razdelimo na (1) tiste, ki so napredovali in s pomočjo VP povečali svojo samostojnost, (2) tiste, pri katerih je bil viden trend napredovanja, vendar ga nismo uspeli z gotovostjo potrditi, ter na (3) tiste, pri katerih nismo zaznali sprememb. Dodatno smo preverili, kakšno je stanje na ravni vseh vključenih $v$ raziskavo, zato smo uporabili $t$ preizkus povezanih vzorcev primerjave srednjih vrednosti potrebne pomoči za obdobji pred in po uvajanju VP, s katerim smo z gotovostjo potrdili izboljšanje samostojnosti pri celotnem vzorcu $(P=0,008)$. Rezultat preizkusa je potrdil zaznana izboljšanja pri določenih učencih, obenem pa so opažena tudi 
izboljšanja v primeru drugih učencev, ki pa niso bila statistično značilna. Analiza tudi potrjuje, da pri enem učencu uporaba VP ni bila učinkovita, kar kaže na to, da je treba uvesti spremembe. Posledično ugotavljamo, da je treba VP individualizirati glede na individualne značilnosti in potrebe učencev $z$ MDR (Mechling 2007; Kidder in McDonnell 2017). Nekateri učenci namreč lahko izkažejo povečano samostojnost pri določenih korakih, obenem pa upad samostojnosti pri drugih, kar potrjuje domnevo, da enaka oblika VP ne more biti učinkovita pri vseh (Van Laarhoven idr. 2009).

\section{Sklep}

Pričujoča raziskava, $v$ kateri smo prikazali primer uvajanja VP za umivanje rok pri učencih z MDR, osvetljuje področje VP in ga umešča v polje dela z učenci z MDR. Pomaga nam razumeti, kako lahko VP prispevajo k samostojnosti učencev z MDR. Ob upoštevanju individualnih značilnosti in potreb učencev z MDR so VP učinkovit pristop pri razvijanju samostojnosti. Do podobnih ugotovitev so prišli različni avtorji (Duttlinger idr. 2013; Mirenda 2001; Copeland in Hughes 2000).

Ob tem naj poudarimo, da je pri preverjanju učinkovitosti VP pomembno spremljati tudi povečanje natančnosti, hitrost odzivanja ali pridobivanja posamezne spretnosti (Cohen in Gerhardt 2016) in ne zgolj splošnega napredka učenca. Le tako lahko načrtujemo bolj usmerjeno razvijanje samostojnosti učenca z MDR s pomočjo VP. Kot ključna ugotovitev se kaže tudi pomembnost razlage VP učencem in večkraten prikaz njihove pravilne uporabe predvsem v fazi njihovega uvajanja ter preizkušanja.

$\checkmark$ prihodnje bi bilo raziskavo smiselno izvajati dlje časa in ugotavljati, ali učenci z MDR VP za umivanje rok dejansko uporabljajo tudi, ko niso opazovani, saj bi s tem izključili vpliv t. i. Hawthornovega učinka oz. vpliv raziskovalčeve udeležbe na vedenje udeležencev $v$ raziskavi (McCambridge, Witton in Elbourne 2014). Prav tako bi bilo smotrno opazovati, ali so učenci, pri katerih so se VP izkazale kot uspešen pristop, sposobni generalizacije ter s tem dejanskega doseganja večje samostojnosti. Raziskava je imela tudi omejitve. Prva je zagotovo majhno število udeleženih v raziskavi, zaradi katerega je pridobljene podatke težko posplošiti na celotno populacijo. Druga je, da smo učence spremljali le pet dni po uvajanju VP, zato pridobljeni podatki kažejo le stanje takoj po uvajanju VP, ne pa tudi trajnosti njihovega prispevka k samostojnosti udeleženih $v$ raziskavi. $Z$ dosežki raziskave prikažemo pomembne ugotovitve, ki bi utegnile imeti tako znanstveno (ugotavljanje dejanske učinkovitosti VP pri učencih z MDR) kot uporabno vrednost (smernice za nadaljnje strokovno delo $z$ učenci z MDR). 


\section{Literatura}

American Psychiatric Association. 2013. Diagnostic and Statistical Manual of Mental Disorders: DSM-5. Arlington, VA: American Psychiatric Association.

Bouck, E. C., in J. Park. 2019. »Special Education Transition Services for Students with Intellectual Disabilities. «V Special Education Transition Services for Students with Disabilities, ur. J. P. Bakken in F. E. Obiakor, 53-67, Advances in Special Education, Vol. 35. Bingley: Emerald.

Buckley, S., G. Bird, B. Sacks in T. Archer. 2006. »A Comparison of Mainstream and Special Education for Teenagers with Down Syndrome: Implications for Parents and Teachers. "Down Syndrome Research and Practice 9 (3): 5467.

Charlop-Christy, M. H., M. Carpenter, L. Le, L. A. LeBlanc in K. Kellet. 2002. »Using the Picture Exchange Communication System (PECS) with Children with Autism. "Journal of Applied Behavioral Analysis 35 (3): 213-231.

Cohen, A., in M. Demchak. 2018. »Use of Visual Supports to Increase Task Independence in Students with Severe Disabilities in Inclusive Educational Settings. "Education and Training in Autism and Developmental Disabilities 53 (1): 84-99.

Cohen, M. J., in P. F. Gerhardt. 2016. Visual Supports for People with Autism. Bethesda, MD: Woodbine House.

Copeland, S. R., in C. Hughes. 2000. »Acquisition of a Picture Prompt Strategy to Increase Independent Performance." Education and Training in Mental Retardation and Developmental Disabilities 35 (3): 294-305.

DeBoer S. R. 2007. How to Do Discrete Trial Training. Austin, TX: PRO-ED.

Demšar, D. 2017. Premagovanje ovir v komunikaciji. Ljubljana: Beletrina.

Duttlinger, C., K. M. Ayres, A. Bevill-Davis in K. H. Douglas. 2013. »The Effects of A Picture Activity Schedule for Students with Intellectual Disability to Complete a Sequence of Tasks Following Verbal Directions."Focus on Autism and Other Developmental Disabilities 28 (1): 32-43.

Dyrbjerg, P., in M. Vedel. 2007. Everyday Education: Visual Support for Children with Autism. London: Jessica Kingsley.

Gray, C. 2010. The New Social Story Book. Arlington, TX: Future Horizons.

Grubešič, S. 2014. Posebni program vzgoje in izobraževanja. Ljubljana: Ministrstvo za izobraževanje, znanost in šport in Zavod Republike Slovenije za šolstvo.

Hall, L. J., L. E. McClannahan in P. J. Krantz. 1995. »Promoting Independence in Integrated Classrooms by Teaching Aides to Use Activity Schedules and Decreased Prompts.« Education and Training in Mental Retardation and Developmental Disabilities 3 (3): 208-217.

Hannah, L. 2009. Učenje mlajših otrok z motnjami avtističnega spektra: priročnik za starše in strokovnjake v rednih šolah in vrtcih. Maribor: Center Društvo za avtizem. 
Hart, S., in M. J. Drummond. 2014. "Learning without Limits: Constructing a Pedagogy Free from Determinist Beliefs about Ability. "V The SAGE Handbook of Special Education, ur. L. Florian, 500-515. 2. izd. London: SAGE.

Hodgdon, L. A. 1995. Visual Strategies for Improving Communication. Troy, MI: QuirkRoberts.

ICD-11 for Mortality and Morbidity Statistics (Version 05/20201). B. I. https://icd .who.int/browse11/l-m/en.

Jurišić, B. D. 2011. »Specialnopedagoška obravnava otrok z avtizmom.« V Pediatrična hematologija in onkologija; pediatrična endokrinologija; natologija; pediatrična nevrologija; pediatrična intenzivna terapija; otroška psihiatrija, ur. C. Kržišnik in T. Battelino, 340-356. Izbrana poglavja iz pediatrije. Ljubljana: Medicinska fakulteta, Katedra za pediatrijo.

- 2016. Otroci z avtizmom: priročnik za učitelje in starše. Ljubljana: Izobraževalni center Pika, Center Janeza Levca.

Kidder, J. E., in A. P. McDonnell. 2017. »Visual Aids for Positive Behavior Support of Young Children with Autism Spectrum Disorders.« Young Exceptional Children 20 (3): 103-116.

Koyama, T., in H. T. Wang. 2011. »Use of Activity Schedule to Promote Independent Performance of Individuals with Autism and Other Intellectual Disabilities: A Review. Research in Developmental Disabilities 32 (6): 2235-2242.

Mahour, P., in S. Panday. 2015. »Changes in Intellectual Disability in DSM-5.« International Journal of Contemporary Issues in BehaviouralSciences 1 (2): 4650.

McCambridge, J., J. Witton in D. R. Elbourne. 2014. "Systematic Review of Hawthorne Effect: New Concepts Are Needed to Study Research Participation Effects." Journal of Clinical Epidemiology 67 (3): 267-277.

Meadan, H., M. M. Ostrosky, B. Triplett, A. Michna in A. Fettig. 2011. »Using Visual Supports with Young Children with Autism Spectrum Disorder.« Teaching Exceptional Children 43 (6): 28-35.

Mechling, L. C. 2007. »Assisitive Technology as a Self-Management Tool for Prompting Students with Intellectual Disabilities to Initiate and Complete Daily Tasks: A Literature Review.«Education and Training in Developmental Disabilities 42 (3): 252-269.

Ministrstvo za šolstvo in šport. 2004. Učni načrt za področje razvijanje samostojnosti: posebni program vzgoje in izobraževanja; prvi del osnovnošolske ravni. Ljubljana: Ministrstvo za šolstvo in šport in Zavod Republike Slovenije za šolstvo.

Mirenda, P. 2001. »Autism, Augmentative Technology and Assistive Technology: What Do We Really Know?« Focus on Autism and Other Developmental Disabilities 16 (3): 141-152.

Mitchell, D. 2014. What Really Works in Special and Inclusive Education: Using Evidence-Based Teaching Startegies. New York in London: Routledge. 
Pierce, K. L., in L. Schreibman. 1994. »Teaching Daily Living Skills to Children with Autism in Unsupervised Settings Through Pictorial Self-Management." Journal of Applied Behavioral Analaysis 27 (3): 471-481.

Quinn, M. 2016. »Promoting Independence among Children with Disabilities at the Milwaukee Center for Independence. "Journal of Childhood \& Developmental Disorders 2 (3): 1-3.

Rao, M. S., in B. Gagie. 2006. "Learning through Seeing and Doing: Visual Supports for Children with Autism. «Teaching Exceptional Children 38 (6): 2633.

Salvador-Carulla, L., G. M. Reed, L. M. Vaez-Azizi, S.-A. Cooper, R. Martinez-Leal, M. Bertelli, C. Adnams, S. Cooray, S. Deb, L. Akoury-Dirani, S. C. Girimaji, G. Katz, H. Kwok, R. Luckasson, R. Simeonsson, C. Walsh, K. Munir in S. Saxena. 2011. »Intellectual Developmental Disorders: Towards a New Name, Definition and Framework for 'Mental Retardation/Intellectual Disability' in ICD11.« World Psychiatry 10 (3): 175-180.

Servatius, J. D., M. Fellows in D. Kelly. 1992. »Preparing Leaders for Inclusive Schools."V Restructuring for Caring and Effective Education: An Administrative Guide to Creating Heterogeneous Schools, ur. R. A. Villa, J. S. Thousand, W. Stainback in S. Stainback, 267-283. Baltimore, MD: Brookes.

Spriggs, A. D., W. van Dijk in P. J. Mims. 2015. »How to Implement Visual Activity Schedules for Students with Disabilities. $D A D D$ Online Journal: Research to Practice 2:21-34.

Stokes, H., M. Turnbull in J. Wyn. 2013. Young People with a Disability: Independence and Opportunity. Melbourne: Youth Research Centre.

Thompson, J. R., K. A. Shogren in M. L. Wehmeyer. 2016. »Supports and Support Needs in Strengths-Based Models of Intellectual Disability. « In Handbook of Research-Based Practices for Educating Students with Intellectual Disability, ur. M. L. Wehweyer in K. A. Shogren, 31-49. New York: Routledge.

Van Laarhoven, T., L. K. Chandler, A. McNamara in L. M. Zurita. 2009. »A Comparison of Three Prompting Procedures: Evaluating the Effectiveness of Photos, AAC, or Video-Based Prompting for Teaching Cooking Skills to Young Children with Developmental Disabilities."Assistive Technology Outcomes and Benefits: Research-Based Practice and Innovation in the Field: 1-17.

Wilken, E. 2012. Jezikovno spodbujanje otrok z Downovim sindromom: z izčrpnim prikazom KPK sistema - s kretnjami podprte komunikacije. Ljubljana: Sekcija za Downov sindrom pri Društvu Sožitje in Pedagoška fakulteta.

\section{A Path to Achieving Independence for Children With Intellectual Disability: Teaching Hand Hygiene Using Visual Support}

Visual support, as a scientifically supported approach, can contribute to increasing the autonomy and independence of students with intellectual disabilities in transition, as they help them learn and develop lifelong skills and 
thus integrate into the social environment. We analysed the adequacy of visual support in a special education programme as an approach for the development of independence in handwashing in students with moderate intellectual disabilities. Six students were included in the study. They were first monitored three days before the introduction of visual support, followed by a five-day introduction of visual support through example and guided use, and then a five-day monitoring period of independent usage of visual supports. The improvement in independence was confirmed with certainty at the level of the entire sample and in two students. Three students showed progress that was not statistically typical. We did not detect any progress in one student. We confirmed the adequacy of the approach of visual support in developing the independence of students with intellectual disabilities.

Keywords: visual support, transition to independence, hand washing, intellectual disabilities, special education programme 